\title{
O DIREITO E STATUS JURÍDICO DOS ANIMAIS NÃO-HUMANOS
}

\section{ARTIGO ORIGINAL}

MORAES, Marianna Machado ${ }^{1}$

MORAES, Marianna Machado. O direito e status jurídico dos animais nãohumanos. Revista Científica Multidisciplinar Núcleo do Conhecimento. Ano. 06, Ed. 10, Vol. 07, pp. 100-125. Outubro 2021. ISSN: 2448-0959, Link de Acesso: https://www.nucleodoconhecimento.com.br/lei/animais-nao-humanos

\section{RESUMO}

Este artigo aborda os direitos fundamentais dos animais não-humanos, contrapondo o movimento da ética animal ao avanço legislativo. A questão que norteou a pesquisa foi: o avanço da legislação protetiva aos animais sencientes tem sido suficiente para proteger os animais não-humanos no Brasil? Com vistas a responder o problema proposto, o presente artigo objetiva discutir o avanço da legislação protetiva aos animais sencientes em uma perspectiva política, jurídica e ética. A metodologia empregada no desenvolvimento desta pesquisa foi a pesquisa bibliográfica, realizada a partir da consulta a livros, artigos, jurisprudência e legislações que se dedicam ao estudo dos direitos dos animais não-humanos. Foi visto que no Brasil, a questão das vaquejadas, bem como muitos outros atos de maus-tratos aos animais, não deixa dúvida de que no estágio em que a legislação brasileira se encontra atualmente, os animais não têm recebido uma proteção efetiva. Já a Legislação Portuguesa, parece ser mais efetiva que a brasileira. Tratase de um estatuto jurídico que deixou de tratar os animais como objetos para considerá-los seres dotados de sensações e sentimentos. Ao final do estudo

\footnotetext{
${ }^{1}$ Mestre em Ciências Jurídico Políticas pela Universidade Portucalense; PósGraduada em Direito Público pela Universidade Estácio de Sá; Graduada em Direito pela Universidade Gama Filho.
}

RC: 99821

Disponível em: https://www.nucleodoconhecimento.com.br/lei/animais-nao-humanos 
concluiu-se que a Legislação Portuguesa poderia servir para inspirar o legislativo brasileiro a respeitar mais os animais e para motivar o parlamento a dar celeridade aos projetos de lei sobre a matéria.

Palavras-chave: Animais, Direito, Especismo, Proteção.

\section{INTRODUÇÃO}

A sociedade evoluiu com o passar do tempo, mas com as novas tecnologias da informação e comunicação essa evolução parece não estar conseguindo acompanhar todo o processo. As normas precisam se adequar à nova realidade social em que cada vez mais os animais são reconhecidos como seres sencientes e dotados de direitos, e caso não se adeque, estar-se-á incorrendo em retrocesso ou em grande injustiça. O direito aos animais parece avançar a passos lentos principalmente pelo status jurídico que ocupam.

A relação jurídica se estabelece quando direitos e deveres convergem e, no caso, os humanos são sempre os sujeitos de direitos, até mesmo quando se tem como parte envolvida uma pessoa jurídica, por exemplo, são os interesses do homem que são garantidos. Sabe-se, também, que há pouco tempo as mulheres não possuíam direitos e, foi a partir da evolução social, que surgiu o entendimento de que os direitos deveriam ser igualitários e, que, dessa forma, a sociedade evoluiria. Pensese complementarmente que na época da escravidão, onde era senso geral que os escravos não possuíam direitos e que, portanto, poderiam ser tratados como coisas, pois não possuíam personalidade jurídica. A sociedade avançou e a legislação acompanhou a evolução da mentalidade social.

O mesmo não ocorreu com os animais não humanos, que são tratados como seres inferiores, sem direitos positivos, tratamento este decorrente da construção social denominada especismo, que é o preconceito em razão da espécie (Dhont; Hodson;

RC: 99821

Disponível em: https://www.nucleodoconhecimento.com.br/lei/animais-nao-humanos 
Leite, 2016). Porém, com o reconhecimento da igual consideração dos interesses dos animais poder-se-ia avançar no especismo, que como todo preconceito incutido na sociedade, atrasa a evolução desta e paralisa o avanço legislativo.

A Constituição Federal brasileira de 1988 protege a fauna e a flora, mas não reconhece os animais como seres sencientes, ou mesmo como entes despersonalizados não humanos, que poderiam ter seus interesses defendidos processualmente através de representantes legais, assim como já ocorre em outros casos no Brasil.

Portanto, o problema que norteou esta pesquisa foi: o avanço da legislação protetiva aos animais sencientes tem sido suficiente para proteger os animais não-humanos no Brasil?

Com vistas a responder o problema proposto, o presente artigo objetiva discutir o avanço da legislação protetiva aos animais sencientes no Brasil em uma perspectiva política, jurídica e ética.

É fato que os animais estão cada vez mais próximos dos humanos e que homem e animais vivem no mesmo habitat natural usufruindo e compartilhando tudo que está disponível. Dessa forma, saber conviver com todos os seres e usar a racionalidade e tecnologia para evitar o sofrimento animal não é um ato somente jurídico, mas, principalmente, de empatia e solidariedade.

A metodologia empregada no desenvolvimento desta pesquisa foi a pesquisa bibliográfica, realizada a partir da consulta a livros, artigos, jurisprudência e legislação que se dedicam ao estudo dos direitos dos animais não-humanos.

RC: 99821

Disponível em: https://www.nucleodoconhecimento.com.br/lei/animais-nao-humanos 


\section{ANIMAL: TITULAR OU NÃO DE DIREITOS?}

São intrínsecos alguns direitos dos animais não humanos, a exemplo do direito à vida, o direito ao não sofrimento, à liberdade e à alimentação. Esses direitos devem estar dispostos em normativas, assegurando-se a esses seres ao menos o mínimo de proteção, a fim de que se evite que haja violação a esses direitos básicos. A Constituição garante direitos básicos e fundamentais aos humanos, mas no que concerne aos direitos dos animais, a situação é complexa e um tanto contraditória (CARVALHO, 2016).

Como será visto adiante, as legislações de países europeus, a exemplo de Portugal, Alemanha e Holanda, são mais avançadas que a legislação brasileira e demonstrar essa carência de proteção aos animais não-humanos na legislação do Brasil.

No século VI a.C, Pitágoras já falava sobre a crença na transmigração da alma e do respeito aos animais, Plutarco, Porfírio e Plotino[2] também eram adeptos da defesa aos animais, já Aristóteles defendia que eles estavam no planeta apenas para servir aos humanos, pois eram irracionais[3]. Descartes, já no século XVII, falava que os animais não tinham alma e por isso podiam ser maltratados[4].

Rousseau, no século XVIII, defendia que os homens também são animais, e que assim sendo, são passíveis das mesmas sensações que os animais não humanos. Por essa razão, o homem teria ao menos o dever de não maltratar os animais (DESCARTES, 2019).

Ainda no século XVIII - ano que a fundamentação teórica a respeito do tema se firmou - Humphry Primatt em "uma dissertação sobre o dever de compaixão e o pecado da crueldade contra os animais brutos" defende a igualdade moral entre os animais não humanos e humanos (RYDER, 1992, p. 13).

RC: 99821

Disponível em: https://www.nucleodoconhecimento.com.br/lei/animais-nao-humanos 
O filósofo inglês Jeremy Benthan, influenciado por Humphry, falou sobre o sofrimento animal. A Teoria de Benthan é utilizada até hoje pelos defensores de animais, tendo em vista que ela desconsidera a capacidade de raciocínio como fator determinante para o sofrimento. Se o raciocínio fosse condição para o sofrimento, poderia-se dizer que um humano com problema mental, incapaz de raciocinar sobre coisas básicas, também seria incapaz de sofrer e deveria ser tratado como coisa e igualado assim aos animais não humanos. Porém, isso não acontece e é inconteste que pessoas com problemas mentais também sofrem (BENTHAN, 1974).

No livro de Bentham "Uma introdução aos princípios morais e da legislação" ele diz que:

Talvez chegue o dia em que o restante da criação animal venha a adquirir os direitos que jamais poderiam ter-lhe sido negados, a não ser pela mão da tirania. Os franceses já descobriram que o escuro da pele não é razão para que um ser humano seja irremediavelmente abandonado aos caprichos de um torturador. É possível que um dia se reconheça que o número de pernas, a vilosidade da pele ou a terminação do osso sacro são razões igualmente insuficientes para abandonar um ser senciente ao mesmo destino. $O$ que mais deveria traçar a linha intransponível? A faculdade da razão, ou, talvez, a capacidade da linguagem? Mas um cavalo ou um cão adulto são incomparavelmente mais racionais e comunicativos do que um bebê de um dia, de uma semana, ou até mesmo de um mês. Supondo, porém, que as coisas não fossem assim, que importância teria tal fato? O problema não consiste em saber se os animais podem raciocinar; tampouco interessa se falam ou não; o verdadeiro problema é este: podem eles sofrer? (BENTHAN, 1974, p. 69).

Os animais não-humanos, tal como ocorre com os humanos, buscam o prazer e não desejam a dor e o sofrimento. A capacidade de sofrimento depende de consciência e não de ser racional. É uma condição suficiente ter o mínimo de consciência para ser sujeito de consideração jurídica e ética (CABRAL, 2015).

Já no século XIX, a primeira obra jurídica é lançada, "Direito dos Animais: Considerações em relação ao progresso social" escrito pelo professor britânico Henry Stephens Salt (1894) em que evidencia que os animais são possuidores de RC: 99821

Disponível em: https://www.nucleodoconhecimento.com.br/lei/animais-nao-humanos 
direitos. Em 1973, o psicólogo britânico Richard D. Ryder fala sobre o especismo para definir a discriminação entre os animais humanos e não humanos. Logo depois, em 1975, Peter Singer (2008) lançou o livro "Libertação Animal" que utilizava essa ideia do especismo. Singer entrou para o hall da lista dos maiores defensores de animais.

Peter Singer rompe com as barreiras imposta pela ética tradicional, especialmente a de matriz kantiana, cujo respeito e consideração voltam-se exclusivamente para o ser humano. A sua proposta ética, a partir da obra Animal Liberation, publicada em 1975, transborda os limites do antropocentrismo e contraria, assim, o critério da espécie para a atribuição de dignidade a um ser. Com efeito, Peter Singer (2008, p. 7) resgata a formulação do pensamento de Bentham e afirma que é "a capacidade de sofrimento como característica vital que concede a um ser o direito a uma consideração igual”. A capacidade de sofrer ou de estar feliz não depende da linguagem nem da razão, como equivocadamente supunha a ética tradicional. Nesse sentido, para o referido autor, "a capacidade de sofrimento e alegria é, no entanto, não apenas necessária, mas também suficiente para que possamos afirmar que um ser tem interesses - a um nível mínimo absoluto, o interesse de não sofrer" (SINGER, 2008, p. 7).

A Declaração Universal dos Direitos dos Animais foi proclamada pela UNESCO (Organização das Nações Unidas para a Educação, a Ciência e a Cultura) em 27.01.1978, em Bruxelas.

Regan e Singer (1989) em "Direitos dos animais e obrigações humanas" diz que todo animal é considerado sujeito com vida e por essa razão deve ter paz para viver do modo em que sua natureza determina, de sua própria maneira, e sempre em busca do equilíbrio necessário.

RC: 99821

Disponível em: https://www.nucleodoconhecimento.com.br/lei/animais-nao-humanos 
No Brasil, o parágrafo $2 .^{\circ}$ do artigo 445 do Código Civil dispõe que: "Tratando-se de venda de animais, os prazos de garantia por vícios ocultos serão os estabelecidos em lei especial, ou, na falta desta, pelos usos locais [...]" (BRASIL, 2002, s.p.). Além desse artigo, o 1.397 do mesmo diploma legal, estabelece a quem pertence as crias dos animais, o artigo 1.442 diz que eles também podem ser objeto de penhor.

Ocorre que o Projeto de Lei 27/2018 aprovado pelo Senado brasileiro no dia 7 de agosto de 2019 determina que os animais não podem mais ser considerados coisas pelo Código Civil, podendo ser defendidos juridicamente em casos de maustratos[5].

A Carta Magna do Brasil em seu artigo 225 parágrafo 1ํㅡ, inciso VII atribuiu ao Poder Público o encargo de proteção da flora, da fauna, vedadas as práticas que provoquem a extinção de espécies ou que submetam os animais à crueldade, dedicando um capítulo da Carta Magna ao tema. Seria o mandamento uma regra ou princípio constitucional? Tendo em vista que o texto fala expressamente em vedação de práticas cruéis, esta é uma regra, um mandamento constitucional, que nem sempre é respeitado como no caso das vaquejadas.

A Lei $n .09 .605$ de 12 de fevereiro de 2008 dispõe sobre as sanções penais e administrativas derivadas e que as condutas e atividades lesivas ao meio ambiente são passíveis de pena a quem abusar, maltratar, ferir ou mutilar animais de toda espécie. A pena se estende, ainda a quem praticar experiência dolorosa ou cruel a animal vivo, mesmo que seja para fins científicos.

Complementarmente, a Lei n. 11.794 de 8 de outubro de 2008 estabelece procedimentos para o uso científico de animais, atribuindo às Comissões de Experimentação Animal o cumprimento da lei. Ela ratifica a proibição de experiência com os animais quando existir recursos alternativos.

RC: 99821

Disponível em: https://www.nucleodoconhecimento.com.br/lei/animais-nao-humanos 
Já a resolução n.. 879 do Conselho Federal de Medicina Veterinária reconhece os animais como seres sencientes que sentem dor, felicidade, medo e outros sentimentos como os dos humanos. Apesar da importância da resolução para a evolução do tema, as menções dos animais nas leis em vigor no Brasil são meramente reguladoras e não inclusivas, ainda os tratando como objeto. Eles não são considerados de forma individual, não têm reconhecidamente ainda o direito a vida e a liberdade.

O PL 631/2015 do Senado, já tem em seu escopo a ideia de um futuro estatuto dos animais para o Brasil, tendo em vista que o país é signatário da Convenção sobre Comércio Internacional de Espécies da Flora e Fauna Selvagem em Perigo de Extinção (CITES) e da Declaração Universal dos Direitos dos Animais proclamada pela UNESCO, que consideram que o animal tem direitos a serem observados. Porém, apesar disso não conta ainda com uma regulação própria sobre bem-estar animal.

François Ost (1997 apud CAVALCA, 2012, p. 383) pondera que:

[...] atribuir direitos às "entidades não convencionais" (embriões, gerações futuras, espécies, rios, montanhas, animais...) não é desde logo, o essencial. O importante é assegurar-Ihes uma tomada de consideração jurídica: um estatuto jurídico definido pela lei.

Finalmente, é preciso notar a Carta Mundial da Natureza, recepcionada pela Assembleia Geral das Nações Unidas, em 28.10.1982, que traduz uma filosofia egocêntrica, precisamente em seu preâmbulo: "Toda a forma de vida é única e merece ser respeitada, qualquer que seja a sua utilidade para o homem" (ONU, 1982, s.p.).

Portanto, os animais são sujeitos de direitos subjetivos.[6]

RC: 99821

Disponível em: https://www.nucleodoconhecimento.com.br/lei/animais-nao-humanos 


\section{O ANIMAL COMO OBJETO DO DIREITO PRIVADO}

Nesta seção aborda-se a necessidade de superação do enquadramento do animal como objeto do direito no âmbito do direito privado. Para tanto, discute os caminhos para a efetivação jurídica da proteção dos animais para, na sequência, ser possível debruçar-se sobre a análise dos maus tratos decorrentes da prática das vaquejadas.

O alcance dos direitos fundamentais é a expressão máxima da evolução dos seres e das coisas. É o que se pode chamar de proibição do retrocesso (CAVALCA, 2012).

Ruth Harrison (apud WEBSTER, 2005), em 1964 propôs cinco liberdades que deveriam ser respeitadas com vistas a assegurar o bem-estar animal (necessidades nutricionais, ambientais, sanitárias, comportamentais e psicológicas). Segundo a autora, tal como os seres humanos os animais têm necessidades básicas como as elencadas na pirâmide de Maslow. A pirâmide de Maslow, projetada para as necessidades humanas, está dividida em 5 escalas: em sua base estão as necessidades fisiológicas; na sequência está a necessidade segurança, convívio social, estima e, por fim, a necessidade de realizações pessoais. No caso dos animais, tem-se no topo, as necessidades nutricionais e fisiológicas, que implica a ter acesso a água e alimentação adequada; na sequência está a necessidade ambiental, que implica em estar livre de desconforto, tendo um local adequado para descanso e abrigo; necessidades sanitárias, que significa que deve ser protegidos de injúrias, doenças e dor; necessidades comportamentais, que é a liberdade que o animal tem de expressar os comportamentos que são comuns à sua espécie; e, por fim, as necessidades psicológicas, que implica em estar livre de medo e estresse.

Segundo Lourenço (2008), em geral os discursos de proteção aos animais visam propor um tratamento igualitário entre homens e animais, tornando estes sujeitos de direito e igual aos seres humanos. No entanto, deve-se ao menos buscar formas de combater as condutas ilegais e imorais que prejudicam os animais, causando-lhe

RC: 99821

Disponível em: https://www.nucleodoconhecimento.com.br/lei/animais-nao-humanos 
sofrimentos desnecessários. É desejável que os animais sejam tratados com solidariedade e da forma menos gravosa, devendo a sua convivência com o homem transcorrer sem abusos.

Nesse sentido, a filósofa Kantiana, Christine Korsgaard (2008) compara a atitude e a preocupação moral com os animais, com a preocupação que se tem com os prisioneiros de guerra. Segundo a autora, quando o homem usa os animais para alcançar os seus fins, deve fazê-lo da forma mais "humana" possível. Assim, se o homem vai continuar a comê-los, os animais devem ser preservados em condições agradáveis e o abate deve ser feito de forma que o animal não sofra; se as experimentações forem realizadas, o sofrimento deve ser minorado ao máximo; se a caça for permitida, o caçador deve zelar para que a morte do animal seja rápida, evitando-se o terror prolongado ou o sofrimento. Para ilustrar sua ideia, Korsgaard (2008) faz uma comparação aos prisioneiros de guerra, que embora sejam visto como inimigos devem ser tratados de uma forma que deixa clara o reconhecimento da humanidade compartilhada pelos demais seres humanos. Com relação aos animais, se continuarão a ser tratados como recursos úteis, deve ser reconhecida sua condição de seres conscientes e sencientes.

Recorde-se que a Declaração Universal dos Direitos dos Animais[7] foi proclamada pela UNESCO em 27.01.1978, em Bruxelas. Referida carta de princípios reflete no direito interno, pois, o Brasil é um dos países signatários da citada Declaração. O texto normativo possui três artigos que são pertinentes para a abordagem do presente tema. São eles: artigo 3.[8], artigo 10. [9] e artigo 11.ํ [10] (UNESCO, 1978).

Trazendo a pesquisa aqui abordada para um contexto de Direito Internacional, citase Daniel Moura Borges (2015) um dos inúmeros juristas que distingue hard Law de soft Law[11]. Esta última, a soft law é de interesse do presente estudo. Miguel Santos Neves (2016) também apresenta uma definição de soft Law. O autor explica, 
ainda, que a adoção da soft law tem natureza voluntária e poderia se concretizar através de "combinação de partes" ou "benchmarking"[12] e que as boas práticas tidas como orientações normativas, quando violadas, poderiam impor uma sanção não jurídica, porém, eficaz, em que a pressão ao destinatário poderia ocorrer.

Neves (2016, p. 253) teoriza alguns conceitos de soft Law. Um deles seria a "soft law primária", que tem como destinatária a comunidade internacional e tem como principal papel a criação de novos princípios que até a sua criação não tinham sido objeto de nenhuma outra norma internacional. Estes princípios devem servir como pilar de novas áreas do direito internacional, que até a sua criação, não teriam sido objeto de regulação por alguma hard law.

Sendo assim, insta salientar que a Declaração Universal dos Direitos dos Animais tem servido como instrumento de soft law nos tribunais do Brasil.

Um exemplo de sua utilização foi no ano de 2010, em um julgamento proferido no por um juiz da Comarca de Ilhabela, que fica no Estado de São Paulo, onde o juiz da causa exigiu a demolição e a reconstrução de um abrigo para animais daquele município. A decisão[13] cita trecho que traz os comandos normativos da Declaração Universal dos Direitos dos Animais[14].

Apesar da sua utilização como fundamento, o magistrado ressalta que não obstante esta Declaração não obrigue as nações, não se pode ignorar que se trata de uma exortação que serve, ao menos, como uma orientação moral (LEVY, 2017).

Já no município de Rondonópolis, que fica no Estado do Mato Grosso, em 2015, na comarca de Rondonópolis (MT), o Ministério Público propôs a Ação Civil Pública n.ำ 791020 pedindo que a Administração Pública municipal implementasse uma diversidade de medidas com o objetivo de assegurar o bem-estar e o controle populacional de animais abandonados do município. O Ministério Público decidiu engajar-se se na ação após a constatação de que a prefeitura do referido município RC: 99821

Disponível em: https://www.nucleodoconhecimento.com.br/lei/animais-nao-humanos 
levava a cabo ações com vistas ao extermínio de animais abandonados, usando como justificativa, o controle de zoonose. A magistrada Milene Pereira Beltramini, ao conceder medida liminar, fundamentou sua decisão na Declaração Universal dos Direitos dos Animais.

Assim, reafirma-se aqui a importância da Declaração Universal dos Direitos dos Animais de 1978 como instrumento de soft law para que os juízes do país possam amparar suas decisões com a interpretação da norma com a finalidade de coibir as práticas que possam causar sofrimento aos animais não humanos.

\section{OS MAUS-TRATOS SOB A ÓTICA DA FILOSOFIA ANIMALISTA: O EXEMPLO DAS VAQUEJADAS}

No Brasil, segundo Ferreira (2018), o Direito Animal se orienta no sentido de dispersar os conceitos produzidos pela filosofia animalista: a consciência e a senciência, a dignidade e o valor inerente a cada animal. A partir desses achados da filosofia (e da ciência), o Direito Animal edifica sua própria normatização e cientificidade, emancipando-se, assim, do Direito Ambiental. Os animais, para o Direito Animal, interessam por si próprios, independentemente da sua função ecológica ou ambiental.

Não obstante, por que, apesar dessa densidade normativa, gerada pelo próprio texto constitucional, o Direito Animal brasileiro ainda engatinha como um campo jurídico a influenciar decisões e políticas? A resposta, no entendimento de Ataíde Júnior (2018) continua a mesma: o direito positivo não reconhece, ainda, que os animais são titulares de direitos fundamentais, direitos fundamentais de 4. ${ }^{2}[15]$ dimensão.

A título de exemplificação, observe-se que no julgamento do Supremo Tribunal Federal sobre a proibição da vaquejada (em Portugal, tourada), atividade intrinsecamente cruel com os bovinos e equinos envolvidos, o Min. Luís Roberto

RC: 99821

Disponível em: https://www.nucleodoconhecimento.com.br/lei/animais-nao-humanos 
Barroso, embora reconheça a "inevitabilidade histórica" do Direito Animal (e do vegetarianismo), afirma que mesmo que ainda não seja reconhecido aos animais a titularidade de direitos jurídicos, estes são seres sencientes e têm, ao menos, o direito de não serem submetidos à crueldade e maus tratos.[16]

Como informa Baltazar (2019), a vaquejada surgiu no século XIX, na região do Nordeste brasileiro. Naquele tempo, as fazendas de pecuária não possuíam cercas para separar o gado. Assim, não era incomum que boiadas de diferentes fazendeiros se misturassem pelos pastos. Quando os vaqueiros precisavam separar os seus bois, alguns animais apresentavam dificuldade de locomoção e era preciso puxá-los pelos seus rabos e derrubá-los ao chão. Com o tempo, os vaqueiros foram criando habilidade na atividade e a prática de derrubar o boi se transformou em um esporte.

Conforme informações extraídas do site Nexo (2016), enquanto esporte é praticada por pares de vaqueiros, cada um montado em seu respectivo boi, cujo objetivo é encurralar o boi do vaqueiro adversário e derrubá-lo puxando-o pelo rabo. A dupla vencedora é a que consegue acumular maior número de pontos. Para conseguir conquistar todos os pontos, é necessário deixar o animal com as quatro patas apontadas para cima. $\mathrm{O}$ fato de o boi ser derrubado pelo rabo pode submeter $\mathrm{O}$ animal a graves ferimentos e lesões, principalmente na região da coluna vertebral.

Geuza Leitão, em breves linhas, define a realidade das vaquejadas destacando os requintes de crueldades que são aplaudidos pelo público:

O espetáculo é realmente chocante para uns, delirante e enlouquecedor para outros [...]. O espaço onde o novilho ou garrote vai correr é diminuto e dois cavaleiros adestrados acompanham a vítima, emparelhados cada um tentando segurar a cauda do animal que é jogado ao chão sucedendo as mais das vezes, que leva na mão a cauda do animal caído e este muitas vezes tem as patas quebradas desastrosas. Enquanto isso a multidão delira numa expansão esfuziante e histérica de gritos e apupos. Tanto o cavalo

RC: 99821

Disponível em: https://www.nucleodoconhecimento.com.br/lei/animais-nao-humanos 
como a rês mutilada são sacrificados a tiro ali mesmo diante a multidão desassisada (LEITÃO, 2002, p. 17).

Siqueira Filho et al (2015) informam que o evento das vaquejadas movimenta valor monetário de grande monta.No entanto, segundo Baltazar (2019), somente no ano de 2013, a atividade moveu mais de 50 milhões de reais, e, em 2017, ficou constatado que a atividade gerou mais de 700 mil empregos, a partir da cadeia produtiva mantida pelo esporte.

Embora supostamente disfarçada de uma natureza cultural e esportiva, a realidade é que a vaquejada tem demonstrado que pode ocasionar práticas cruéis, acarretando a disseminação de diversas formas de maus-tratos contra os bovinos, especialmente os maus tratos físicos.

A Lei n. ${ }^{\circ} 15.299 / 2013$ é uma lei estadual, aprovada no dia 8 de janeiro de 2013, com o objetivo de regulamentar a prática da vaquejada no Estado entendendo-a como uma atividade esportiva e cultural de grande representatividade no Estado.

Contra este diploma legal, foi proposta a Ação Direta de Inconstitucionalidade (ADIN) $n . \cong 4983$, formulou-se pedido liminar para a suspensão imediata da eficácia da Lei Estadual n. $-15.299 / 2013$, tendo como objetivo principal o pedido para que fosse declarada a inconstitucionalidade da lei.

A ação foi fundamentada na tese de inconstitucionalidade de um diploma legal do Estado do Ceará (a já citada Lei n.ำ15.299/2013) por afronta ao direito fundamental ao meio ambiente, reconhecendo a existência, no entanto, de conflito entre a preservação do meio ambiente e a proteção conferida às manifestações culturais.

Defendeu o parquet a prevalência, no caso, do direito ao meio ambiente, por considerar que a prática da vaquejada - mesmo que considerada como manifestação cultural ou esporte e que movimente milhões de reais - causa, comprovadamente, danos irreversíveis aos animais, expondo-os a maus tratos.

RC: 99821

Disponível em: https://www.nucleodoconhecimento.com.br/lei/animais-nao-humanos 
Ademais, ressaltou-se que a jurisprudência da Corte Maior já havia consolidado o entendimento de que o conflito entre meio ambiente e manifestações culturais, quando exista prática que trate os animais de forma inadequada, precisa ser solucionado em prol do meio ambiente, como em casos concretos, a exemplo da "briga de galo" e da "farra do boi". Por esta razão, em meio a outras causas, a prática da vaquejada também foi declarada inconstitucional, considerando-se o respeito a teoria dos precedentes consolidados sob pena inclusive de se desconstituir a nova ordem processual civil.

A ADIN n. 4983/CE foi distribuída e teve como Relator o Ministro Marco Aurélio Mello, que em 27.07.2013, indeferiu a medida liminar, por entender que pela natureza da discussão deveria ser aguardada a decisão definitiva de mérito. Oficiouse o Governador do Ceará, a Assembleia Legislativa do Ceará, bem como a Advocacia Geral da União para manifestação e o Procurador Geral da República para parecer.

Em 26.08.2013 o Governador do Ceará foi chamado a prestar informações, ocasião em que defendeu a constitucionalidade da Lei impugnada, sob o fundamento de que a vaquejada integra a cultura daquele estado, sendo reconhecida já há muitas décadas como uma prática desportiva, bem como a citada Lei Estadual buscou regulamentar a atividade, para assegurar a proteção da integridade dos animais participantes.

A Assembleia Legislativa do Ceará não prestou informações. Em 06.09.2013 a Advocacia Geral da União (AGU) apresentou manifestação, alegando, em síntese, preliminarmente inépcia da petição inicial por, supostamente, o autor não ter se desincumbido do ônus da impugnação específica, por não apontar os artigos que a lei impugnada estaria violando a Constituição da República Federativa do Brasil de 1988 (CRFB/1988). Entretanto, no mérito, pugnou pela procedência da ação, pela declaração de inconstitucionalidade da Lei Estadual, pelos fundamentos elencados

RC: 99821

Disponível em: https://www.nucleodoconhecimento.com.br/lei/animais-nao-humanos 
pelo autor, notadamente a jurisprudência do Supremo Tribunal Federal (STF) que reconhece que a proteção ao meio ambiente prevalece sobre práticas culturais e desportivas. Referidas informações são as mais importantes para que as questões referentes à crueldade sejam discutidas.

O Relator Ministro Marco Aurélio sublinhou que naquela Ação, foi ressaltado pelo Relator que o STF, em se tratando de temas envolvendo crueldade contra os animais, tem reiterado, em diversos julgamentos, que esta prática se mostra frontalmente incompatível com o que dispõe o artigo 225.ํ, $\S 1 .$. , inciso VII, da CRFB/1988 (BRASIL, 2016).

Assim, permanece o raciocínio intelectual esposado por Ferreira (2018), que dispõe que existindo prova de maus tratos aos animais, em eventos de natureza cultural ou desportiva, a interpretação sobre a primazia de um sadio direito ao meio se mostra a conclusão mais correta.

O Relator também afirma que existem estudos que demonstram que os cavalos utilizados na vaquejada também sofrem danos muitas vezes irreparáveis e de grande magnitude: tendinite, tenossinovite, exostose, miopatias focal e por esforço, fraturas e osteoartrite társica.

No caso, foi destacado pelo Relator que o autor agrupou laudos técnicos que esclarecem sobre os danos suportados pelos animais devido à intensa tração no rabo, aliado às quedas, patas fraturadas, vasos sanguíneos distendidos, traumas e ligamentos rompidos. Em casos mais graves pode ocorrer até mesmo o arrancamento do rabo, o que compromete a medula espinhal e causa, além de intensas dores físicas, estresse ao animal. Em seu voto, o ministro Marco Aurélio esclarece que as argumentações defendendo a constitucionalidade da norma, sob a alegação de que se a prática for disciplinada é possível preservar a saúde dos animais, não subsiste posto que em razão da forma como é desenvolvida, 
indiscutivelmente a crueldade para com os bovinos é inerente à vaquejada. $\mathrm{O}$ ato de perseguir animal em movimento e em alta velocidade, puxá-lo pelo rabo até que este caia, configura maus-tratos. Não existe possibilidade de o boi, quando submetido a esses tratamentos, não sofrer com estresse ou com a dor física (BRASIL, 2016).

Por derradeiro, ao fim de sua longa e cuidadosa argumentação, o Ministro relator votou pela Inconstitucionalidade da lei, tendo em vista que o sentido da palavra "crueldade" que consta ao fim do inciso VII do $\S 1 .^{\circ}$ do artigo $225 .^{\circ}$ da CRFB/1988, atinge, indiscutivelmente, a tortura, crueldade e os maus-tratos contra os bovinos no decorrer da prática impugnada, revelando-se intolerável referida conduta humana. Finalizou o seu voto justificando que para compor os interesses fundamentais em discussão, a proteção ao meio ambiente e, consequentemente, ao animal que padece de maus-tratos, deveria avultar (BRASIL, 2016).

Assim, o Ministro relator interpretou o inciso VII, do $\S 1 .^{\circ}$, do artigo 225.․, da Magna Carta, em que a expressão "crueldade" alcançaria a tortura e maus-tratos aos quais os bois são submetidos durante as vaquejadas e que essa conduta humana não poderia ser consentida pela lei atacada.

Nesse contexto, a proteção ao meio ambiente deveria se sobressair em relação à

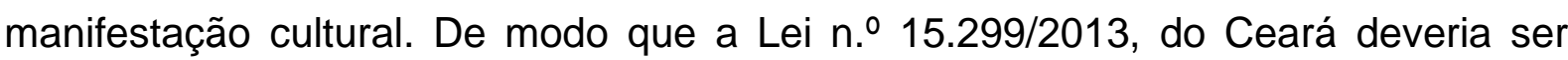
considerada inconstitucional. Assim, esse foi o posicionamento adotado pela maioria da Corte.

Complementarmente, adverte o Ministro Barroso que a vaquejada, no entendimento da própria Associação Brasileira de Vaquejada é vista como uma "atividade recreativa competitiva, com características de esporte" (BRASIL, 2016, s.p.) que se transformou a partir da década de 1990, em um grande evento, capaz de atrair multidões que tinham interesse não somente na competição, mas também nas atrações que o evento reunia, especialmente exibição de shows musicais. Afirma

RC: 99821

Disponível em: https://www.nucleodoconhecimento.com.br/lei/animais-nao-humanos 
que não é possível negar seu caráter de manifestação cultural tradicional, mas que se trata de evento onde a crueldade contra os animais ocorre e nenhuma manifestação poderia evitar a prática a que esses animais são submetidos, e a vedação de crueldade contra os animais deve ser considerada norma autônoma, não podendo a proteção aos animais se dar com vista a preservação do meio ambiente, pois os animais não humanos não podem ser reduzidos simplesmente a elementos do meio ambiente (BRASIL, 2016).

Para o Ministro Luiz Roberto Barroso, é preciso proteger os animais contra a crueldade não somente como uma função da tutela destinada a outros bens jurídicos, mas sim como um valor autônomo (BRASIL, 2016).

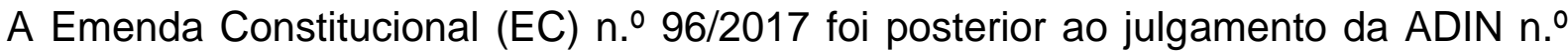
4983 e vai de encontro ao posicionamento adotado pelo STF na ADIN julgada, no entanto, trata-se de conflito apenas aparente de normas, pois, não se pode considerar como manifestação cultural uma prática que implique em sofrimento a um ser vivo.

Os conceitos de cultura e características mostram a diversidade conceitual, mas, no seu conjunto, possibilitam entender o que é cultura. Weschenfelder (2019) afirma que os conceitos de cultura e suas características são tantas quantas são as culturas. Dos conceitos e características referidos extraímos o seguinte: a) há diversas culturas; b) não existe hierarquia quando se trata de cultura, tendo em vista que todas são culturas; c) a cultura é uma construção do homem; d) os seres humanos não são imunes às influências de culturas; e) a cultura varia no tempo e no espaço; f) a cultura tem uma variedade de saberes, artes, religiões, moral, leis, ética, direito, tipos de família, usos e costumes; g) é possível a mudança de uma cultura, assim como criar outra.

RC: 99821

Disponível em: https://www.nucleodoconhecimento.com.br/lei/animais-nao-humanos 
Na linha dessa noção de cultura, na ADIN $n .94983 / C E$, em que foi apreciada a constitucionalidade de lei do Estado do Ceará sobre a vaquejada, o Ministro Edson Fachin, citando as pontuações acima realizadas a partir de conceitos de cultura, asseverou em seu voto que em uma sociedade aberta e plural como é o caso da sociedade brasileira, a noção de cultura é construída e se encontra estreitamente relacionada a uma noção mais ampla do que a que se tem de meio ambiente (BRASIL, 2016).

Se o artigo 7. entende que não é crueldade o uso de animais em práticas desportivas se estas forem manifestações culturais também o inciso VII, do parágrafo primeiro do artigo 225. vem assegurar a incumbência do Poder Público na proteção da fauna e da flora, vedando práticas que ameacem sua função ecológica e que levem à extinção de espécies ou instituam a crueldade contra os animais.

Como demonstra Ferreira (2014), preservar o meio ambiente e os animais não humanos em razão da sua função ecológica são princípios constitucionais e, portanto, fundamentos do Estado de Direito. Deste modo, há novas linhas de conduta que são impressas e captadas paulatinamente pela sociedade, ensejando uma crescente mudança de consciência tendo em vista as crises ambientais e os maus-tratos aos animais.

Ademais, persiste o entendimento de que o Poder Público deve proteger a fauna e flora e consequentemente, interditar as práticas que coloquem em risco sua função ecológica.

Também, a proteção aos direitos dos animais pode ser observada nos princípios trazidos pela Convenção da Biodiversidade (CDB) e outro ponto importante da Convenção mencionado por Azevedo et al. (2005) é o reconhecimento da importância dos conhecimentos tradicionais para a manutenção da biodiversidade.

RC: 99821

Disponível em: https://www.nucleodoconhecimento.com.br/lei/animais-nao-humanos 
Conforme referido, o protecionismo aos animais fortaleceu-se com o teor da Carta de 1988, a qual elevou os bens ambientais à condição de bem público, passando a receber uma especial atenção por parte do legislador por meio do artigo 225.-,$\S 1$ 1.- $^{\circ}$ inciso VII, o qual, abrigando toda e qualquer classificação de animais, obrigou o Poder Público a dedicar proteção à fauna.

A vedação constitucional da crueldade alicerça uma inovadora mentalidade do legislador, atrelada à inserção no sistema normativo nacional de parâmetros novos, a permear a relação jurídica entre homens e animais não humanos.

Deve-se diferenciar a proteção da fauna e da flora, da expressa vedação de práticas que submetam os animais a crueldade, em que se concebe uma identificação do animal não humano com interesses próprios e autônomos se comparados com os dos humanos.

Assim, o legislador constitucional elegeu parâmetros de grande importância que não podem ser ignorados, esquecidos ou desprezados pelo aplicador do Direito e, dentre estes, encontra-se a normatividade protetiva, que renega os maus-tratos.

Saliente-se que esta prescrição está contida no Título VIII da CRFB/1988, que versa sobre a Ordem Social e caberá ao Estado e à coletividade proteger os animais contra a crueldade, como fruto das garantias de bem-estar e da justiça sociais.

No direito brasileiro, portanto, o ponto de partida para a defesa dos interesses dos

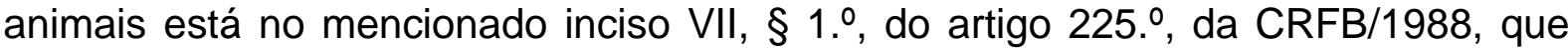
proíbe, "na forma da lei", as práticas cujo efeito material seja a submissão dos animais à crueldade.

De fato, como acertadamente expõe Ferreira (2014), a CRFB/1988, pela primeira vez na história, elevou a proibição da crueldade contra os animais ao status de preceito constitucional e, em respeito ao princípio da efetividade, não se admite

RC: 99821

Disponível em: https://www.nucleodoconhecimento.com.br/lei/animais-nao-humanos 
qualquer exploração institucionalizada dos animais sem que essa norma constitucional seja violada.

Faz-se necessário reconhecer que os animais são seres sensíveis, cabendo a todos respeitar a vida, oferecendo os meios para que a norma constitucional expressa no

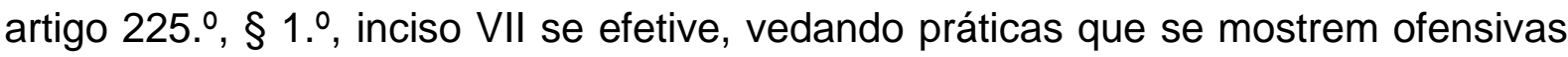
e degradadoras da integridade física destes, e banindo a crueldade e todo modo de exploração.

Frente a este aparente conflito de normas entende-se que a norma que institucionaliza os maus-tratos aos animais não pode prevalecer.

\section{OS DIREITOS DOS ANIMAIS NO DIREITO COMPARADO}

Cotejando-se os direitos de um ser humano com os direitos dos animais não humanos como indivíduo ou espécie, observa-se que ambos têm direito de ter seus direitos fundamentais defendidos, a exemplo do direito à vida, ao livre desenvolvimento de sua espécie, da integridade de seu organismo, além do direito ao não sofrimento. Em uma ótica ética e científica, não é difícil justificar a personalidade do animal. Segundo Peter Singer:

[...] a compreensão do princípio da igualdade aqui aplicado é tão simples que não requer mais que a compreensão do princípio da igualdade de interesses. Se quisermos comparar o valor de uma vida com outra, teremos que começar por discutir o valor da vida em geral (SINGER, 2006, p. 59).

Nesse contexto, convém destacar que a emergência da temática dos direitos humanos a partir dos anos de 1970 trouxe o aprofundamento da sua teoria, a ampliação da sua positividade e a irradiação da jus fundamentalidade para outros campos do direito e para outras áreas do conhecimento jurídico. Entre estes últimos surge o direito dos animais, como objeto de regramento e de especulação jurídica e ética.

RC: 99821

Disponível em: https://www.nucleodoconhecimento.com.br/lei/animais-nao-humanos 
A legislação da Alemanha se mostra progressista, especificamente no que tange ao artigo § 90a[17] do Código Civil germânico (BGB), incluído pela reforma legislativa de 1990 e que dispõe que os animais não são coisas.

Observa-se que o fundamento subjacente a esse dispositivo está no reconhecimento de uma parcela de dignidade também aos animais com fundamento no valor da vida (não somente a humana, mas a vida animal em geral).

Este dispositivo é, na realidade, de grande importância, primeiramente em razão da influência que o Direito germânico sempre exerceu e permanece exercendo sobre os demais sistemas jurídicos, inclusive o brasileiro. Em segundo lugar, tendo em vista que o citado comando parece guardar coerência e harmonia com o atual estágio do pensamento social geral sobre o direito à dignidade aos animais não-humanos $e$ com os valores sociais.

A Constituição da Alemanha exerceu notável influência sobre a nova problemática, mercê da inclusão do artigo $20 .^{\circ}$ no texto fundamental: "O Estado protege também por responsabilidade com as futuras gerações os fundamentos naturais da vida e os animais" (GARCIA, 2012, p. 362).

Restou claro, portanto, a partir da mudança da Constituição germânica efetuada em 2002 e das conquistas atuais da teoria dos direitos fundamentais, que, embora ainda não possuam os animais direitos em nome próprio, expande-se o quadro de suas garantias sob a proteção maior dos direitos humanos. A afirmação dos direitos humanos passa necessariamente pela preservação e expansão dos direitos dos animais. Consoante bem observa Lourenço (2008, p. 15), "não há sobrevivência para os direitos do homem se não envolverem os animais e a proteção de todo o meio ambiente. Assim, a ideia da superioridade dos direitos absolutos do homem vai perdendo o seu colorido nos últimos anos".

RC: 99821

Disponível em: https://www.nucleodoconhecimento.com.br/lei/animais-nao-humanos 
A título exemplificativo, pode-se citar o Tratado de Roma, marco legislativo da União Europeia, que foi recentemente emendado (pelo Tratado de Amsterdam, em 10.11.1997) para reconhecer que os animais, incluindo aqueles, destinados ao abate para consumo, são seres sencientes, devendo tal fato ser levado em consideração para a implementação das políticas comuns nas áreas da agricultura, pesquisa e transporte. Em 1999 a União Europeia proibiu a criação intensiva de galinhas em gaiolas (a partir de 2012) e a produção de vitela por meio de imobilização (a partir de 2007), entre outras medidas.

Atualmente, segundo Ferreira (2018), em todo o mundo há esforços para aperfeiçoar a legislação protetiva aos animais. A título de exemplificação, a Holanda proíbe a criação de cães da raça Pug e de outros cães braquicefálicos, já que estes animais sofrem com a dificuldade respiratória; em Roma é proibida a criação de peixinhos dourados para aquário; a Áustria proíbe que galinhas sejam mantidas em gaiolas apertadas e que cães e gatos sejam expostos em vitrines de lojas; na França, o proprietário que deixar um cão dentro do carro em dias de sol pode receber uma multa no valor de 750 euros; a Bolívia proíbe o uso até de pombos em espetáculos circenses; na Polônia, há uma lei que proíbe que cães sejam mantidos em coleiras por mais de 12 horas seguidas; Moscou proíbe que animais sejam explorados para tirar fotos junto aos turistas.

Nos países escandinavos (Noruega, Finlândia, Dinamarca e Islândia), como expõe Striwing (2002), algumas legislações se mostram bastante evoluídas no que se refere à proteção dos animais. Na Noruega, há uma lei de bem-estar animal que define os padrões reais para o cuidado aceitável dos animais. No caso da Dinamarca, Katariya (2018) explica que a leis de bem-estar animal norueguesa foi alterada recentemente para ter precedência sobre a religião, quando o país proibiu o abate de animais vivos em cultos religiosos. 
Já o site Animal Welfare Act (2009) noticia que a lei de bem-estar animal norueguesa aplica-se às condições que afetam o bem-estar ou respeito pelos mamíferos, aves, répteis, anfíbios, peixes, decápodes, lulas, polvos e abelhas.A legislação aplica-se igualmente às fases de desenvolvimento dos animais referidos nos casos em que o aparelho sensorial é equivalente ao nível de desenvolvimento dos animais vivos. Neste país, é proibido o abandono de animais em condição indefesa, ter interação sexual ou realizar atividades sexuais com animais, o uso de cercas de arame farpado para limitar o tráfego de animais e o uso animais vivos como alimento ou isca. Também, prevê normas rígidas para caça, captura, pesca, criação, treinamento, exibição, entretenimento, competição, comércio e uso em pesquisa.

\section{CONSIDERAÇÕES FINAIS}

No Brasil, a questão das vaquejadas bem como muitos outros atos de maus-tratos aos animais não deixa dúvida de que no estágio incipiente em que a legislação brasileira se encontra atualmente, os animais não têm recebido uma proteção efetiva. Assim, defende-se à luz do Direito Comparado, que seja editada no Brasil, uma legislação efetiva na proteção aos animais.

Já a Legislação Portuguesa parece ser mais efetiva que a brasileira. Esta legislação, que foi elaborada para proteger os animais de forma a evitar maus-tratos, foi aprovada por unanimidade pelo Parlamento português ainda em dezembro de 2016 . Trata-se de um estatuto jurídico de Portugal que deixou de tratar os animais como objetos para considerá-los seres dotados de sensações e sentimentos. A alteração legislativa integra a Lei $n .{ }^{\circ}$ 8/2017, que cuida dos deveres dos proprietários dos animais.

A lei estabelece que o animal de estimação deverá ser tratado de forma a ter o seu bem-estar assegurado e, aquele que descumprir as exigências trazidas pelo texto

RC: 99821

Disponível em: https://www.nucleodoconhecimento.com.br/lei/animais-nao-humanos 
legal, poderá arcar com obrigações que podem levar o proprietário a pagar multas de elevado valor ou mesmo ser preso. Além dos animais de estimação, como explica Costa (2017), a Lei Portuguesa contempla também a necessidade de cuidar dos animais envolvidos na agropecuária.

A partir da mudança legislativa, Portugal passou a integrar um pequeno rol de países europeus que possuem estatutos jurídicos que atuam em defesa dos direitos dos animais.

A Revista Exame (2019) notícia que o parlamento brasileiro tem discutido a respeito do tema. Em 07.08.2019, o Senado Federal, em sessão plenária, aprovou projeto de lei que cria regime jurídico específico para os animais. O Projeto de Lei Complementar $n . .27 / 2018$, os animais não poderão mais ser considerados como objetos. Como a matéria do texto foi modificada no Senado, o projeto retornou para a Câmara dos Deputados. Referido projeto de lei muito se assemelha à Lei Portuguesa, haja vista que ele determina que os animais passarão a ter uma natureza jurídica sui generis na condição de sujeitos de direitos despersonificados, posto que serão reconhecidos como seres sencientes, ou, melhor dizendo, dotados de natureza biológica e emocional, além de serem passíveis de sofrimento.

Sem deixar de apreciar a Declaração Universal dos Direitos dos Animais, a nova Legislação Portuguesa e o projeto de lei brasileiro, também podem servir como forma de inspiração para as decisões judiciais brasileiras no contexto de coibição das atividades das vaquejadas.

Não só como inspiração judicial, a Legislação Portuguesa poderia servir para inspirar o legislativo brasileiro a respeitar mais os animais e para motivar o parlamento a dar celeridade aos projetos de lei sobre a matéria, isso sob o prisma de respeito aos animais enquanto seres dotados de sentimentos, bem como respeito

RC: 99821

Disponível em: https://www.nucleodoconhecimento.com.br/lei/animais-nao-humanos 
à fauna e a flora, de modo a conferir maior efetividade ao que o direito constitucional denomina de meio ambiente saudável e equilibrado.

\section{REFERÊNCIAS}

Animal Welfare Act. 10.07.2009. Disponível em: https://www.regjeringen.no/en/ dokumenter/animal-welfare-act/id571188/. Acesso em: 12 Jan. 2021.

Ataide Junior, V.P. Introdução ao Direito Animal brasileiro. Revista Brasileira de Direito Animal. Salvador, v. 13, n. 3, p. 48-76, set./dez. 2018.

AZEVEDO, C.M.A. et al. A convenção sobre a diversidade biológica no Brasil: considerações sobre sua implementação no que tange ao acesso ao patrimônio genético, conhecimentos tradicionais associados e repartição de benefícios. Revista de Direito Ambiental, a. 10, n. 37, p 113-143, jan./mar. 2005.

BALTAZAR, S.M. Justiça Ecológica. Curitiba: Juruá Editora, 2019.

BENTHAM, J. Uma introdução aos princípios da moral e da legislação. São Paulo: Abril Cultural, 1974.

Borges, D.M. A Declaração Universal dos Direitos dos Animais: sua aplicação enquanto Soft Law e Hard Law. [Em linha]. Dissertação de Mestrado em Relações Sociais e Novos Direitos. Salvador, Universidade Federal da Bahia. 2015, p.35. Disponível em: https://repositorio.ufba.br/ri/bitstream/ri/18719/1/DANIEL\%20MOURA \%20BORGES.pdf. Acesso em: 30 Dez., 2020.

BRASIL. Constituição da República Federativa do Brasil de 1988. Disponível em: http://www.planalto.gov.br/ccivil_03/constituicao/constituicao.htm. Acesso em: 30 Dez. 2020. 
BRASIL. Lei n. 10.406, de 10 de Janeiro de 2002. Institui o Código Civil. Disponível em: http://www.planalto.gov.br/ccivil_03/leis/2002/110406compilada.htm. Acesso em: 30 Dez. 2020.

BRASIL. Lei 11.794 de 08 de outubro de 2008. 9. ed. São Paulo: Saraiva, 2013.

BRASIL. Supremo Tribunal Federal. Ação Direta de Inconstitucionalidade - ADIN no 4.963. Rel. Ministro Marco Aurélio. Julg. 15.12.2016. Publ. 31.01.2017. Disponível em: http://portal.stf.jus.br/processos/detalhe.asp?incidente=4425243. Acesso em: 30 Dez., 2020.

CABRAL, F. Fundamentação dos Direitos dos Animais: a existencialidade jurídica. Alfarroba: Lisboa, 2015.

CARVALHO, G.F.S.S. A tutela jurídica dos animais: evolução histórica e conceitos contemporâneos. In: Congresso Brasileiro de Direito Ambiental, 21., 2016, São Paulo. Anais eletrônicos, 2016, v. II.

Cavalca, R.F. O Direito Constitucional Internacional e os animais: a tutela dos animais como sujeitos de direitos. In: Garcia, M; Gamba, J.C.M; Montal, Z.M.C. (Coords.). Direito Constitucional Internacional. Curitiba: Juruá Editora, 2012, p. 379-381.

COSTA, D. Portugal: lei determina que animais são seres sencientes e não objetos. 2017. Disponível em: http://blogs.revistaencontro.com.br/petcetera/2017/04/10/portu gal-lei-determina-que-animais-são-seres-sencientes-e-nao-objetos/.Acesso em: 30 Dez., 2020.

Descartes, R. Discurso sobre a Origem da Desigualdade. 2019. Disponível em: http://www.dominiopublico.gov.br/pesquisa/DetalheObraForm.do?select_action $=\&$ co_obra=2284. Acesso em: 30 Dez., 2020.

RC: 99821

Disponível em: https://www.nucleodoconhecimento.com.br/lei/animais-nao-humanos 
Dias, E.C. A defesa dos animais e as conquistas legislativas do movimento de proteção animal no Brasil. Fórum de Direito Urbano e Ambiental, Belo Horizonte: Fórum, n. 17. set./out. 2004. p. 1918-1926.

EXAME. "Não é coisa": projeto de lei reconhece que animais têm sentimentos. [Em linha]. Revista Exame. 2019. Disponível em: https://exame.abril.com.br/brasil/nao-ecoisa-projeto-de-lei-reconhece-que-animais-tem-sentimentos/. Acesso em: 1 Jan. 2021.

FERREIRA, A.C.B.S.G. A Proteção aos Animais e o Direito: o Status Jurídico dos Animais como Sujeitos de Direito. Curitiba: Juruá Editora, 2014.

Ferreira, A.C.B.S.G. Direito Animal em Xeque. Curitiba: Juruá Editora, 2018

GARCIA, M.; GAMBA, J.C.M.; MONTAL, Z.M.C. Direito Constitucional Internacional. Curitiba: Juruá Editora, 2012.

Jornal da Serra da Cantareira. Despacho do Juiz Dr. Cavalcanti: jurisprudência em favor da proteção animal. 13.07.2010. Disponível em: http://www.jornaldaserra.com.br/2Bichos/llhabela/llhabeladespacho.htm. Acesso em: 30 Dez. 2020.

\section{KATARIYA, M. 8 Countries With The Strictest Animal Welfare Laws In The World}

That India Can Take Cues From. 2018. Disponível em: https://www.scoopwhoop.com/countries-with-strict-animal-welfare-laws-in-the-world/. Acesso em: 12 Jan. 2021.

KORSGAARD, C. Just Like All The Other Animals of the Earth. Harvard Divinity Bulletin, v.36, n.3, pp.1-3, 2008. Disponível em: http://bulletin.hds.harvard.edu/ articles/autumn2008/just-all-other-animals-earth. Acesso em: 30 Dez. 2020.

LEITÃO, G. A voz dos sem voz: Direito dos animais. Fortaleza: INESP, 2002. RC: 99821 
Levy, S. Jurisprudência deveria ser aproveitada em favor da proteção animal. Vegan News. 2017. Disponível em: http://www.vegannews.com.br/2017/05/24/ jurisprudencia-deveria-ser-aproveitada-em-favor-da-protecao-animal/. Acesso em: 30 Dez. 2020.

Lima, M.P. Curso de direito processual penal. 2. ed. Rio de Janeiro: LumenJuris, 2006.

LOURENÇO, D.B. Direito dos animais: fundamentação e novas perspectivas. Porto Alegre: SAFE, 2008

Machado, P.A.L. Direito ambiental brasileiro. 24. ed. São Paulo: Malheiros, 2016.

Neves, M.S. Soft Law in Introdução ao Estudo do Direito. Almedina, Coimbra, 2016.

NEXO. O que é vaquejada. E porque ela foi proibida pelo Supremo. 2016. Disponível em: https://www.nexojornal.com.br/expresso/2016/10/16/O-que-\%C3\% A9-a-vaquejada.-E-por-que-ela-foi-proibida-pelo-Supremo. Acesso em: 21 Dez. 2020.

ORGANIZAÇÃO DAS NAÇÕES UNIDAS - ONU. Assembleia Geral das Nações Unidas. Carta Mundial da Natureza. 28.10.1982. Disponível em: https://en.wikipedia.org/wiki/World_Charter_for_Nature. Acesso em: 21 Dez. 2020.

Ost, F. A natureza à margem da lei: a ecologia à prova do direito. Lisboa: Instituto Piaget, 1997.

REGAN, Tom; SINGER, Peter. Animal rights and human obligations. 2. ed. New Jersey: Prentice Hall, 1989. 
RYDER, Richard D. Introdução. In: PRIMATT, Humphry. The Duty of Mercy. Fontwell, Sussex: Centaur Press, 1992.

SALT, H. S. Animal's rights. Considered in relation to social progress. New York Macmillan \& CO and London. 1894. Digitilized by the inyternet archive in 2010 with funding from opn knowledge commoms (for the medical Heritage Library Projetc). 2010. Disponível em: https://archive.org/details/animalsrightsco00salt/page/n3 Acesso em: 23 Out. de 2020.

SINGER, P. Ética prática. São Paulo: Martins Fontes, 2006.

SINGER, P. Libertação animal. Tradução de Maria de Fátima St. Aubyn. Porto: Via Óptima, 2008.

SIQUEIRA FILHO, V.; LEITE, R.A.; LIMA, V.B. A prática da vaquejada em xeque: considerações sobre a Ação Direta de Inconstitucionalidade n. 4.983. Revista Brasileira de Direito Animal, v.10, n.20, p.59-80, 2015.

STRIWING, H. Animal Law and animal rights on the move in Sweden. Animal Law, v.8, n.93, p.93-106, 2002.

UNESCO. Declaração Universal do Direito dos Animais. 1978. Disponível em: http://www.fiocruz.br/bios seguranca/Bis/infantil/direitoanimais.htm. Acesso em: 30 Dez. 2020.

Webster, J. Animal welfare: limping towards Eden. Blackwell Publishing, Oxford, 2005.

Weschenfelder, P.N. Constituição e Cultura Ambiental. Curitiba: Juruá Editora, 2019.

RC: 99821

Disponível em: https://www.nucleodoconhecimento.com.br/lei/animais-nao-humanos 


\section{APÊNDICE - REFERÊNCIA NOTA DE RODAPÉ}

2. Plutarco - depois de sua conversão em cidadão romano, Lucius Mestrius Plutarchus - é o nome de um filósofo e biógrafo grego, nascido em 46 e falecido na mesma cidade de Queroneia, (atual Kaprena, região da Beócia) Grécia, em 119. Um dos expoentes do neoplatonismo, a influência de Porfírio é inferior apenas à de Plotino. Porfírio se dedicou a explicar a lógica de Aristóteles e a defender o neoplatonismo de Plotino.

3. Filósofo grego e matemático (PITAGORAS, 1987).

4. Filósofo, físico e matemático francês autor da celebre frase: "penso logo existo".

5. Matéria disponível no site migalhas. Disponível em: https://www.migalhas.com.br/Quentes/ 17,MI308293,41046Animal+nao+e+coisa+estabelece+PL+aprovado+pelo+Senado. Acesso em: 31 Dez. 2020 .

6. Conforme refere Edna Cardozo Dias, "embora não possam ter identidade civil e ser registrados em cartório, são portadores de direitos inerentes à sua natureza de ser vivo e de indivíduos de uma determinada espécie. Se observarmos que os direitos de personalidade do ser humano lhes pertencem como indivíduo, e se admitirmos que o direito à vida é imanente a tudo que vive, podemos concluir que os animais também possuem direitos de personalidade, como o direito á vida e ao não sofrimento. E tal como os juridicamente incapazes, seus direitos são garantidos por representatividade, tornando-se esses direitos deveres de todos os homens" (Dias, 2004, p. 1918).

7. A Declaração Universal dos Direitos dos Animais é uma carta de princípios reconhecida internacionalmente. Trata-se de proposta de legislação internacional que foi levada por ativistas que atuam em defesa da causa animal à Unesco em

RC: 99821

Disponível em: https://www.nucleodoconhecimento.com.br/lei/animais-nao-humanos 
1978 visando a criação de parâmetros jurídicos sobre os direitos dos animais para os países integrantes da ONU. Cf. a Declaração na íntegra em: http://www.urca.br/ceua/arquivos/Os\%20direitos\%20dos\%20animais\%20UNESCO. pdf. Disponível em: 31 Dez. 2020.

8. Artigo 3a, a) Nenhum animal deverá ser submetido a maltrato e a atos cruéis.

9. Artigo 10, a) Nenhum animal deve ser usado para divertimento do homem. b) A exibição dos animais e os espetáculos que utilizam animais são incompatíveis com a dignidade do animal.

10. Artigo 11. $\mathrm{O}$ ato que leva à morte de um animal sem necessidade é um biocídio, ou seja, um delito contra a vida.

11. "[...] têm-se por hard law as normas cuja obrigatoriedade jurídica possibilitam a aplicabilidade de sanções jurídicas por intermédio de tribunais internacionais ou até mesmo órgãos internos judiciais daqueles países signatários e, por soft law, normas que são consideradas como recomendações, cujo teor levam a preceitos que incentivam determinadas condutas, sem, no entanto, estabelecerem uma obrigatoriedade ou sanção pelo seu descumprimento" (Borges, 2015, p. 35).

12. Benchmarking é um termo empregado em Administração que consiste no processo de busca das melhores práticas de gestão da entidade. Em Direito ambiental o termo é empregue com o mesmo sentido, visando a preservação ambiental e das espécies.

13. A decisão em seu inteiro teor não foi encontrada. A parte citada pode ser acessada em: Jornal da Serra da Cantareira. Despacho do Juiz Dr. Cavalcanti: jurisprudência em favor da proteção animal. 13.07.2010. Disponível em: http://www.jornaldaserra.com.br/2Bichos/llhabela/llhabeladespacho. htm. Acesso em: 30 Dez. 2020.

RC: 99821

Disponível em: https://www.nucleodoconhecimento.com.br/lei/animais-nao-humanos 
14. "Não se pode olvidar, ainda, da Declaração Universal dos Direitos dos Animais, proclamada pela UNESCO em 27.01.1978 em Bruxelas na Bélgica, que, em seu artigo $2^{\circ}$, alíneas "a" e "c", prescrevem que: a) Cada animal tem o direito a respeito. c) Cada animal tem o direito a consideração, à cura e à proteção do homem".

15. Estes direitos versam sobre o futuro da cidadania e a proteção da vida a partir da abordagem genética e suas atuais decorrências

16. VAQUEJADA MANIFESTAÇÃO CULTURAL ANIMAIS CRUELDADE MANIFESTA PRESERVAÇÃO DA FAUNA E DA FLORA INCONSTITUCIONALIDADE. A obrigação de o Estado garantir a todos o pleno exercício de direitos culturais, incentivando a valorização e a difusão das manifestações, não prescinde da observância do disposto no inc. VII do artigo 225 da Carta Federal, o qual veda prática que acabe por submeter os animais à crueldade. Discrepa da norma constitucional a denominada vaquejada (STF, Pleno, ADI 4983, Rel. Min. MARCO AURÉLIO, j. em 06.10.2016, publicado em 27.04.2017). BRASIL. Supremo Tribunal Federal. Ação Direta de Inconstitucionalidade - ADIN no 4.963. Rel. Ministro Marco Aurélio. Julg. 15.12.2016. Publ. 31.01.2017. Disponível em: http://portal.stf.jus.br/processos/detalhe.asp?incidente=4425243. Acesso em: 30 dez. 2020.

17. §90a do Código Civil germânico (BGB) - "Animais não são coisas. Eles são protegidos por leis especiais. A eles se aplicam as normas vigentes para as coisas, no que couber, salvo disposição em contrário."

Enviado: Julho, 2021.

Aprovado: Outubro, 2021.

RC: 99821

Disponível em: https://www.nucleodoconhecimento.com.br/lei/animais-nao-humanos 